\title{
The Effect of Knowledge Sharing and Benefits on Sharing Intentions Through Social Interaction in Social Media Groups
}

Dwi Asih Haryanti" ${ }^{1}$, E. S. Margianti ${ }^{1}$, Edy Prihantoro ${ }^{2}$, Noviawan Rasyid Ohorella ${ }^{2}$

1,2Gunadarma University, Indonesia

${ }^{3,4}$ Master of Communication Science Faculty, Indonesia

\section{ABSTRACT}

\section{Article Info}

Volume 8, Issue 4

Page Number : $310-324$

\section{Publication Issue}

July-August-2021

\section{Article History}

Accepted : 10 July 2021

Published : 20 July 2021
The purpose of this study is to analyze the effect of social interaction on the benefits of sharing knowledge, the effect of expected benefits on sharing knowledge, the effect of expected benefits on the benefits of social media groups, the effect of social interaction on the benefits of social media groups, the effect of knowledge sharing on the benefits of social media groups, the effect of sharing knowledge on intentions. sustainable knowledge sharing, and the effect of the benefits of social media groups on the intention of sustainable knowledge sharing. The sample in this study was 308 respondents consisting of high school/vocational students and D3/S1 students in the Jabodetabek area. Data processing for descriptive statistics and regression using SPSS and Amos software tools. The results of this study that social interaction affects knowledge sharing, expectations of benefits have no effect on sharing knowledge, expectations of benefits affect the benefits of social media groups, social interactions affect the benefits of social media groups, knowledge sharing affects the benefits of social media groups, knowledge sharing has no effect on intention to share knowledge on an ongoing basis, the benefits of social media groups affect the intention to share knowledge on an ongoing basis.

Keywords : Knowledge Sharing, Social Interaction, Benefit Expectation, Social Media Group

\section{INTRODUCTION}

\section{A. Background}

The presence of the internet as a modern communication medium has enabled humans to communicate with everyone around the world. Based on data from the Association of Indonesian Internet Service Providers (APJII) in 2018, the population of
Indonesia was 264.14 million and internet users in Indonesia were 171.17 million people. Based on the age segment, 15-19 year olds have the highest penetration (reaching 91\%). Next is the age of 20-24 years with a penetration of $88.5 \%$; age $25-29$ years $82.7 \%$; age $30-34$ years with a penetration of $76.5 \%$, and the age group of 35-39 years with a penetration of $68.5 \%$. 
Currently, the existence of social media changes the paradigm of communicating in society. Communication is not limited by distance, time, space. Communication can occur anywhere, anytime, without having to face to face. Even social media is able to negate social status, which is often a barrier to communication. Various social media such as Facebook, Twitter, Instagram, Whatsapp and Line allow people to communicate and form a community.

Communication in social media consists of intrapersonal communication, interpersonal communication, group communication, public communication, and mass communication. The largest level of communication with the most communication target coverage is mass communication, which includes social media groups. Uploads of material made by a person can be seen and enjoyed by many audiences, so that communication occurs between members of the group. People communicate on social media with social transparency, which is a condition of the disappearance of social categories, social boundaries, social hierarchies (Piliang, 2004). The behavior and attitudes displayed by the community are related to self-concept to control themselves and not cross ethical boundaries (West \& Turner, 2008). Communication with social media will have an influence on (a) Beliefs, values, and attitudes, (b) Worldview, (c) Social organization, (4) Human nature, (5) Activity orientation, (6) Perception of self and others (Darmastuti, 2011)

Knowledge sharing is a reciprocal process in which individuals exchange knowledge (tacit and explicit knowledge) and jointly create new knowledge (solutions) (Van den Hoof and De Ridder, 2004). One of the goals of this definition consists of imparting and collecting knowledge, which is providing knowledge by communicating knowledge to others what one has of a person's personal intellectual capital, and gathering knowledge refers to consulting by sharing information or their intellectual capital. According to Pasaribu (2009), knowledge sharing can be defined as a culture of social interaction, including the exchange of knowledge between employees, experiences, and skills through entire departments or organizations, this creates a common basis for the need for cooperation. Every process in sharing knowledge is always related to how to collect and provide information or data to others. Through the exchange of knowledge that is carried out both formally and in these interactions, workers can share knowledge or information with their fellow coworkers (Nonaka and Teece, 2001).

According to Babalhavaeji and Kermani (2011), the factors that influence knowledge sharing are attitudes, intentions and intrinsic motivation. People's intention to share knowledge is influenced by subjective attitudes and norms. The intention to share knowledge leads to the behavior of increasing knowledge sharing. From an intrinsic motivation perspective, behavior is elicited by employees' need to feel competent in dealing with their environment. Reciprocal benefits, self-confidence and enjoyment in helping others are considered strong motivations for sharing knowledge. The intrinsic motivation of the source is the most important factor in the knowledge transfer process. According to $\mathrm{Wu}$, Lee, and Tsai (2012), knowledge sharing is a process of learning, exchanging ideas and sharing knowledge in order to increase individual excellence. The main focus of knowledge sharing is people who are willing to be invited to exchange information and knowledge, both other people, groups and organizations.

Benefit expectations (outcome expectations) are positively related to the intention of sustainable users of the online knowledge community. In addition, there may be a correlation between the two personal cognitions. When users have high self-efficacy, they can form positive expectations about future outcomes (Lin and Huang, 2008). Continuous knowledge 
sharing intention is a determinant of the desired behavior to share knowledge (Dong, Liem, and Grossman, 2010). Findings from the studies of Tohidinia and Mosakhani, 2010 and Chatzoglou and Vraimaki, 2009 show the positive influence of intention on knowledge-sharing behavior.

The benefits of social media groups (Community Usefulness) allow users to represent themselves and interact, collaborate, share, communicate with other users and form virtual social bonds. This meaning refers to the social meaning, namely recognition, communication and cooperation (Nasrullah, 2015). The benefits of social media groups include (1) online groups on social media are effective in creating friendships; (2) Friendship is established because of the similarity of status or behavior; (3) Many groups means many friends. Based on the background of previous research, this research was conducted by selecting the title The Effect of Knowledge Sharing and Benefits on Sharing Intentions Through Social Interaction in Social Media Groups.

\section{B. Konceptual}

Communication is a transaction, a symbolic process that requires people to regulate their environment by (1) building relationships between human beings; (2) through the exchange of information; (3) to strengthen the attitudes and behavior of others; and (4) trying to change attitudes and behavior (Cangara, 2011).

Information and communication technology in Indonesia is developing very rapidly, making the internet as the main communication tool that is in great demand by the public. The presence of the internet as a modern communication medium has made the world easier to grasp. Almost everyone has a communication device that makes it possible to communicate with everyone around the world through social media. Social media distorts a lot of existing thinking and theory. The level or level of communication is merged in one container called social networking/social media. Social media is increasingly opening up opportunities for each individual involved in it to freely express their opinions. However, self-control must also be possessed, so that the freedom you have does not violate boundaries and does not offend other parties. Social media or also known as social networking is part of new media. Interactive content in new media is very high.

For many people, online communication actually facilitates the formation of close interpersonal relationships. Because through online communication, each individual involved tends to be more courageous in expressing his opinion, and opening himself up to be known by others. Communication in social media is not bound by time, day or night, the parties involved can still be actively involved. Also not bound by space, with anyone around the world the parties involved in it can communicate. This is not possible in face-to-face contact, including using conventional communication media such as telephone, this is related to costs and time differences. Online communication in this case is seen as cheaper, faster, and easier. (Adler \& Rodman, 2006).

Theory of Communication Technology Determinism. explain the changes that occur in various ways of communicating will also shape human existence itself. So basically there is a change from traditional technology to modern technology. The theory of Technological Determinism was first put forward by Marshall McLuhan in 1962 in his The Guttenberg Galaxy: The Making of Typographic Man. The basic idea of this theory is that changes that occur in various ways of communicating will also shape human existence itself. Technology shapes individuals how to think, behave in society, and this technology directs humans to move from one technology century to another (Nurudin, 2011). 
At this time the use of social media has taken a role in everyday life. Starting from children, teenagers to adults can use social media. Social media content is not like conventional mass media (television, radio, newspapers) which tend to make the audience passive, so that the message content presented is only adapted to the needs of the media. However, social media provides facilities for someone to be able to control the social media content they have. In other words, the user can be a subject (producer) or an object (consumer). Social media has the characteristics of being interactive, participatory and networked. Through social media, a person can communicate himself to the public or obtain information from the public. However, along with the times, the use of social media has also shifted, which was originally used as a medium of communication, now it has become a means of entertainment, information exchange, da'wah, politics to economic interests (onlineshop). Attachment to social media can affect time commitment and communication. Searching for information on social media will lead a person to another series of interesting information, which sometimes does not match the original purpose of the search. Communication in a social context is done for self-fulfillment, to feel comforted, comfortable and at peace with oneself and others. The messages exchanged may be trivial things, but the conversation will make both of them feel happy and comfortable. (Azmi, 2014).

Interaction is a social relationship between individuals in such a way that the individuals concerned influence each other (Chaplin, 2011). According to Gillin and Gilin 1954) social interaction is a dynamic social relationship involving the relationship between individuals, between human groups and between individuals and human groups. When two people meet, social interaction begins at that moment. They reprimand each other, shake hands, talk to each other or maybe even fight. Such activities are forms of social interaction. Interrelated factors in influencing the course of social interaction carried out by each individual. Factors that influence social interaction are imitation factors, suggestion factors, identification factors, and sympathy.

Based on this understanding, it can be said that social interaction is the ability of an individual to conduct social relations with other individuals or groups marked by the existence of social contact and communication, a change from traditional technology to modern technology, which was originally done face-to-face interaction turned into interaction through social media.

Research conducted (Hsu, Chia and Chang, 2007) concludes that there is a growing interest in factors that support or hinder one's knowledge-sharing behavior in virtual communities. To explore knowledge-sharing behavior in a virtual community, this study proposes a social cognitive-based model that includes knowledge-sharing self-efficacy and benefit expectations. Identifying the motivations underlying knowledge sharing behavior in virtual communities will help academics and practitioners gain insight into how to stimulate knowledge sharing in virtual communities. The biggest challenge in fostering virtual communities is the provision of knowledge, namely the willingness to share knowledge with other members, which is important in explaining why individuals choose to share or not share knowledge with other community members when they have a choice.

According to (Gurteen, 1999), Knowledge Sharing is not only limited to providing knowledge to others, but can also be in the form of: requesting/asking for feedback; ask questions; inform others of plans you have to do a job before it is done; ask others for help; tell others about the task/work being done and why the task/job is being done; ask other people's opinion and ask that person's advice; and asking others what they would do with a job. The goal of the knowledge 
sharing process is to spread the knowledge possessed by one person to as many people as possible in the organization. Dissemination of knowledge from one person to another or from one work unit to another is expected to improve the quality of knowledge possessed by individuals, work units and ultimately organizations (Junaida, 2011).

One way for organizations to gain a knowledge-based competitive advantage is to manage knowledge sharing (Argote \& Ingram, 2000). Liebowitz (2001) states that knowledge sharing activities will create value-added benefits in the organization. Knowledge sharing is a tool for organizations in order to generate innovation (Wang \& Yang, 2007). Islam, Ahmad and Mahtab. (2010) stated that knowledge sharing activities help organizations transfer new ideas and solutions. In addition, MacDermott \& O'Dell, (2001) mentions that knowledge sharing enables organizations to identify, promote, and disseminate best practices and Knowledge Sharing Behaviors.

\section{METHODS AND MATERIAL}

This type of research uses quantitative descriptive which aims to make a description or description systematically and the relationship between the phenomena being investigated. This study uses primary data obtained through the distribution of questionnaires or questionnaires to samples that have been determined directly. The samples in this study were high school/vocational high school students and D3 and S1 program students in the Greater Jakarta area and outside Jabodetabek.

The data collection technique used in this study was carried out using a tool or instrument in the form of a questionnaire, in the form of a Likert scale that includes variables of social interaction, benefit expectations, benefits of social media, knowledge sharing and intention to share continuous knowledge, as well as demographic data to describe the characteristics of respondents. The Likert scale is based on the results of a questionnaire distributed through the Google Form tool. survey. With a Likert Scale, the variables to be measured are translated into variable indicators. Questions were scored 1,2,3,4 and 5. The answers to the questions were [1]: Strongly disagree; [2] : Disagree; [3] : Neutral; [4] : Agree; [5] : Totally agree.

\section{RESULTS AND DISCUSSION}

This study uses primary data by providing a link to a questionnaire that is distributed to students and high school / vocational students via google form. The number of incoming questionnaires is 328 . Based on age data, it can be seen that the age of 18 years (29\%), 19 years (28\%), 20 years (16\%), 21 years (10\%), 17 years $(6 \%), 22$ years and more than 23 years were $5 \%$. This is in line with data obtained by the Association of Indonesian Internet Service Providers (APJII) in 2018 aged 15-19 years having the highest penetration (reaching 91\%) of internet users in Indonesia.

Based on gender, the data obtained were $63 \%$ female and $37 \%$ male respondents. This is in line with research conducted by (Helpiastuti, 2020), social media has become the latest communication medium that greatly affects human life, especially women. Based on the survey results, it can be seen that the most dominant social media users are women. This is because in relation to self-identity, women who use social media increase their courage to display their identity. This can be seen from the finding of women who are comfortable with identifying themselves with a given identity. Although it is undeniable, there have also been found women who dare to show their achievements and competencies as the main shapers of their identity. Overall, it shows that the display of women's identity in social media is so complex.

Women as creatures who like to socialize, one of them is by sharing information to communicate 
through social media. Women also use $30 \%$ of their time to communicate through social media, while men only use $26 \%$ of their time to interact on social media (Lubis, 2014). Women spend four to five times more time using social media than men. In addition, Sheldon (2008) found that women prefer social media to connect with family and friends, pass time, entertain, but men prefer to use social media to meet new people. College students prefer to use the internet to communicate and establish relationships, such as contacting friends, family, and their partners (Baym, Zhang, Kunkel, Ledbetter, \& Mei-Chen, in Mahmud \& Omar, 2013).

By region, respondents from Greater Jakarta $96 \%$ and outside Greater Jakarta $4 \%$, this is because the researcher resides in Greater Jakarta and informs the questionnaire to students at Gunadarma University, which is located in Greater Jakarta. Based on 9\% high school education and $91 \%$ D3/S1 students. Respondents were $62 \%$ internet subscribers and $38 \%$ unsubscribed, 94\% subscribed to data packages and $6 \%$ unsubscribed. The amount of credit used is less than 100 thousand as much as $48 \%$ and more than equal to 100 thousand as much as 52\%. Respondents subscribed to internet and data packages for the need to interact using social media. Based on the social media groups followed, $86 \%$ used the group watshapp and $14 \%$ in addition to the group watshapp.

The highest percentage of respondents using social media is whatsapp from 308 respondents (always/every day) as much as $87 \%$ (267 people), often (several days per week) 7\% (23 people), rarely (once a week) as much as $1 \%$ (4 people ), rarely as much as $1 \%$ (3 people) and never as much as $4 \%$ (11 people); The next in a row is Instagram (always/every day) as much as $73 \%$ (225 people), often (several days per week) 15\% (46 people), rarely (once a week) as much as $4 \%$ (13 people), rarely as much as $3 \%$ (10 people) and never as much as $5 \%$ (14 people); Line (always/every day) 40\% (122 people) often (several days per week) $23 \%$ (71 people), rarely (once a week) $21 \%$ (66 people), rarely $8 \%$ (26 people) and never as much as $7 \%$ (23 people); Twitter (always/every day) $21 \%$ (65 people), often (several days per week) 14\% (42 people), rarely (once a week) 17\% (53 people), rarely $17 \%$ (51 people) ) and never $31 \%$ (97 people); and Facebook (always/every day) 9\% (27 people), often (several days per week) 10\% (31 people), rarely (once a week) 14\% (43 people), rarely 34\% (104 people) people) and never as much as 33\% (103 people).

\section{Model Estimation}

\section{Sample Size}

In using the SEM technique with the MLE estimation procedure the recommended number of samples is 100-150 samples, in this study the number of samples was 308 respondents.

2. This normality test can be seen in the values of the Critical Ratio (CR) of the skewness and kurtosis. The data is normally distributed if the CR value of the data is between -2.58 to +2.58 . At this significance level, the $\mathrm{z}$ value obtained from the $\mathrm{z}$ table is \pm 2.58 . In this study, the normality test was met.

\section{Loading Factor}

The standardized loading factor describes the magnitude of the correlation between each measurement item (indicator) and its construct. This value shows the correlation between the indicator and the construct. An indicator with a low loading value indicates that the indicator does not work on the measurement model. expected loading value $>0.7$. In this study the loading factor meets the requirements.

\section{Composite Reliability (CR)}

Composite Reliability (CR) is better at measuring internal consistency. The Composite Reliability (CR) interpretation is the same as Cronbach's Alpha. CR limit value $>0.7$. In this study the $C R$ value $>0.7$.

\section{Average Variance Extracted (AVE)}

The AVE value is used to measure the amount of variance that can be captured by the construct 
compared to the variance caused by measurement errors. The AVE value must be greater (>0.5). In this study, all AVE values were met.

\section{Testing the Feasibility of the Model}

Before testing the hypothesis on the structural model, the Goodness of Fit parameter is calculated. The model fit test/goodness of fit model in the study (hopper, coughlan \& Mullen, 2008) includes 2/df, GFI, NFI, RFI, IFI, TLI, CFI and RMSEA as shown in Table 4.2 as follows:

Table 1. Model Fit

\begin{tabular}{llll}
\hline No. & $\begin{array}{l}\text { Statistics } \\
\text { of Model } \\
\text { Fit }\end{array}$ & $\begin{array}{l}\text { Default } \\
\text { Model }\end{array}$ & $\begin{array}{l}\text { Recommendations } \\
\text { range }\end{array}$ \\
\hline 1. & $\chi 2 /$ df & 2,234 & $2-5$ \\
\hline 2 & GFI & 0.923 & 0.90 \\
\hline 3. & NFI & 0.942 & 0.90 \\
\hline 4. & RFI & 0.946 & 0.95 \\
\hline 5. & IFI & 0.967 & 0.90 \\
\hline 6. & TLI & 0.959 & 0.95 \\
\hline 7. & CFI & 0.967 & 0.90 \\
\hline 8. & RMSEA & 0.027 & $0-0,08$ \\
\hline
\end{tabular}

Note: (") hopper, coughlan \& Mullen (2008)

\section{Discussion}

Hypothesis H1, there is an effect of social interaction on knowledge sharing.

This study is in line with research conducted by (Qureshi, Fang, Haggerty, Compeau, Xiaojie Zhang, 2018) which concluded that in a knowledge-based economy, organizational success depends on how effectively the organization's employees share information. Various types of communication activities and communication media affect knowledge sharing. Social interactions mediated by Information Technology have an effect on knowledge sharing among employees compared to face-to-face social connections. Research on knowledge sharing, social networks, and information systems, concluded that the ability of social interaction mediated by Information Technology is used for (1) interaction between individuals with heterogeneous backgrounds and (2) facilitating high Information Technologymediated social interaction. Research (Ghahtarani. Majid, Mahdieh, 2019) concludes that social interaction has a significant relationship with knowledge sharing. The theory of social interaction was first presented in 1964 by Blaand, generally seeks to explore the basis of individual behavior in sharing knowledge. Based on this theory, the interaction of individuals with each other is based on the theory of cost and benefit analysis. Based on this theory, individuals seek to maximize their profits and minimize costs when exchanging knowledge. (Razak, Pangil, Yunus, Asnawi, 2016). Each individual will look for more advantages in their interactions, individuals can strive to build social relationships to get more benefits, where they can share information in this social relationship with the improvement of technology, social interaction and social relations are developing rapidly in online media. In fact, technology has created a platform for increasing social interaction in online media.

Hypothesis H2, there is no effect of benefit expectations (outcome expectations) on knowledge sharing (knowledge sharing).

This research is in line with (Chao, Hsu, Wang, 2006) which states that the biggest challenge in fostering a virtual community is the willingness to share knowledge with other members. When a member of a knowledge-sharing social media group does not care about the expected results regarding the knowledge provided, but is more concerned about the successful functioning, survival, and growth of the virtual community than the benefits that will be generated by themselves. 
H3: The effect of outcome expectations on the benefits of social media groups (community usefulness).

Based on the results of the study, it is known that the effect between outcome expectations and the benefits of social media groups (community usefulness) has a CR value of 2.158 ( $\mathrm{p}=0.031<0.05)$, meaning that there is an influence between outcome expectations and group benefits. social media (community usefulness). Hypothesis H3, there is an effect of expected benefits (outcome expectation) on the benefits of social media groups (community usefulness). When the community on social media can provide a solution, it will be used as a reference by its members. Therefore, when members believe that they can achieve goals through the community, such as doing better at work, or helping solve workrelated problems, the community is considered useful (Wiertz and de Ruyter, 2007).

H4: The effect of social interaction on the benefits of social media groups (community usefulness).

Based on the results of the study, it is known that the influence between social interaction and knowledge sharing has a CR value of $2.543(\mathrm{p}=0.011<0.05)$, meaning that there is an influence between social interaction and the benefits of social media groups. (community usefulness). Hypothesis $\mathrm{H} 4$, there is an effect of social interaction on the benefits of social media groups (community usefulness). This research is in line with research (Saade, 2007) whose result is that a user will be more likely to perceive social interaction as useful if it can help them achieve personal goals. The results of this study can be utilized by a student who will see an online learning system as more useful if they believe it can help them get better grades. Someone interacts on social media because of the need to socialize and interact with fellow members of social media groups.
H5: The effect of knowledge sharing on the benefits of social media groups (community usefulness).

Based on the results of the study, it is known that the effect of knowledge sharing with the benefits of social media groups (community usefulness) has a $C R$ value of $4.771\left(\mathrm{p}={ }^{* * *}<0.05\right)$, meaning that there is an influence between knowledge sharing and the benefits of social media groups (community usefulness). Hypothesis $\mathrm{H} 5$, there is an effect of knowledge sharing on the benefits of social media groups (community usefulness). The results of the study (Jayasimha, Chaudhary and Chauhan, 2017), stated that consumers' willingness to help others by sharing their own knowledge/experiences can provide benefits to the social media community/group (Hennig, Gwinner, Walsh, \& Gremler, 2004).

Community creates social networks. A strong community will encourage interactions and relationships of mutual trust and respect, this will encourage the desire to share knowledge/ideas, uncover problems, ask questions and listen carefully between individuals. Knowledge sharing among units provides opportunities for shared learning that can stimulate the creation of new knowledge (Ghoshal, 1998). Empirical evidence shows that organizations that can share knowledge effectively between units are more productive and are likely to survive more than organizations that do not adopt knowledge sharing. Knowledge sharing and understanding between individuals and companies can be accomplished well with knowledge sharing technology, which is a tool that provides communication so that knowledge belongs to the community and ultimately belongs to the organization, not to individuals.

H6: The effect of knowledge sharing on continuous knowledge sharing intention. 
Based on the results of the study, it is known that the effect of knowledge sharing with continuous knowledge sharing intention has a CR value of 0.999 $(\mathrm{p}=0.318>0.05)$, meaning that there is no influence between knowledge sharing. with continuous knowledge sharing intention. Hypothesis H6, there is no effect of knowledge sharing on continuous knowledge sharing intention.

In this hypothesis there is no effect of knowledge sharing on the intention to share knowledge continuously (continuous knowledge sharing intention). Communities of Practice theory which states that a group of people who interact with each other in sharing their interests and hobbies, then they learn from each other to become better in their interests and hobbies will share knowledge with each other in a community. When sharing knowledge does not bring benefits, individuals have no intention to share knowledge continuously.

H7: The effect of social media group benefits (community usefulness) on continuous knowledge sharing intention.

Based on the results of the study, it is known that the influence between the benefits of social media groups (community usefulness) and knowledge sharing has a CR value of $6.844\left(\mathrm{p}={ }^{* * *}<0.05\right)$, meaning that there is an influence between the benefits of social media groups (community usefulness). ) by sharing knowledge (knowledge sharing). Hypothesis H7, there is an effect of the benefits of social media groups (community usefulness) on the intention to share continuous knowledge (continuous knowledge sharing intention).

This study is in line with (Hashim, Tan, 2018) the results of this study indicate that the intention of sustainable knowledge sharing can be encouraged through the perceived benefits of online communities. In sharing knowledge, community members will consider a community useful if it can help its users achieve their goals. When using online communities, members' knowledge-sharing behavior is motivated through their goals such as one's moral obligation to the community of interest, or to expand social connections or networks in the hope of mutual benefit (Ardichvili et al., 2003; Wasko and Faraj, 2003). 2005). In addition, being part of a community and contributing to encourage members' willingness to contribute knowledge to their community (Chiu et al., 2006).

The results of research on the benefits of online communities, in the context of sustainable knowledge sharing can be used by online business community owners, because they provide a better understanding of how to encourage members' perceptions of the usefulness of online communities, when using online business communities to promote knowledge sharing intentions on an ongoing basis.

\section{CONCLUSION}

Based on the results of the discussion, the following conclusions are presented from the research as follows:

1. Social interaction has an effect on knowledge sharing. Based on the theory of cost and benefit analysis, individuals will maximize benefits and minimize costs when exchanging knowledge, Information technology in this case is social media that can support users to conduct social interactions to share knowledge without being constrained by distance and time.

2. Benefit expectations (outcome expectations) have no effect on knowledge sharing. It can be proven that a member of a knowledge-sharing social media group does not care about the expected results regarding the knowledge provided, but is more concerned about the successful functioning, survival, and growth of the 
virtual community than the benefits that will be generated by themselves.

3. Benefit expectations (outcome expectations) affect the benefits of social media groups (community usefulness). Members of social media groups believe they will benefit from achieving goals through the community, such as doing better at work, or helping solve work-related problems through social media groups.

4. Social interaction affects the benefits of social media groups (community usefulness). Social media users consider that social interaction is useful to meet the need to socialize and interact with fellow members in social media groups.

5. Knowledge sharing affects the benefits of social media groups (community usefulness). Sharing knowledge and understanding between individuals can be best accomplished with knowledge sharing technology, which is a tool that provides communication so that knowledge belongs to the community.

6. Knowledge sharing has no effect on continuous knowledge sharing intention. It can be proven that when knowledge sharing does not provide benefits to individuals, then there is no intention to share knowledge continuously.

7. The benefits of social media groups (community usefulness) affect the intention to share knowledge continuously (continuous knowledge sharing intention). Knowledge sharing behavior of members of social media groups is motivated through their goals such as one's moral obligation to the community of interest, or to expand social connections or networks in the hope of mutual benefits, so that group members will always have the intention of sharing knowledge on an ongoing basis.

\section{REFERENCES}

[1]. Ackerman, Mark S., Pipek, Volkmar, dan Wulf, Volker. (2003). Sharing Expertise: Beyond
Knowledge Management. London: The MIT Press.

[2]. Adler, R. B., Rodman, G. R., \& Du Pré, A. (2016). Understanding human communication, 10. Oxford University Press.

[3]. Al-Busaidi, K.A. \& Olfman, L. (2017). Knowledge sharing through inter-organizational knowledge sharing systems. VINE Journal of Information and Knowledge Management Systems, 47(1), 110-136.

[4]. Arabshahi, M., Lagzian, M., Rahimnia, F., \& Kafashpour, A. (2013). The impact of emotional intelligence on faculty members' knowledge sharing behaviors. Management Science Letters, 3(12), 2963-2970.

[5]. Ardichvili, A., Page, V., \& Wentling, T. (2003). Motivation and barriers to participation in virtual knowledge-sharing communities of practice. Journal of knowledge management, 7(1), 64-77.

[6]. Argote, L., Ingram, P., Levine, J. M., \& Moreland, R. L. (2000). Knowledge transfer in organizations: Learning from the experience of others. Organizational behavior and human decision processes, 82(1), 1-8.

[7]. Azmi, K. (2014). Filsafat Ilmu Komunikasi. Tangerang: indigo media.

[8]. Asosiasi Penyelenggara Jasa Internet Indonesia. (2020). Retrieved Februari 20, 2020, from https://www.apjii.or.id/

[9]. Becerra, Fernandez, \& Sabherwal, R. (2010). Knowledge Management: Systems and Processes. New York: M.E. Sharpe.

[10].Bircham-Connolly, H., Corner, J., \& Bowden, S. (2005). An empirical study of the impact of question structure on recipient attitude during knowledge sharing. Electronic Journal of Knowledge Management, 32(1), 1-10.

[11].Bock, G. W., Zmud, R. W., Kim, Y. G., \& Lee, J. N. (2005). Behavioral intention formation in knowledge sharing: Examining the roles of extrinsic motivators, social-psychological forces, 
and organizational climate. MIS quarterly, 87111.

[12].Calantone, R. J., Cavusgil, S. T., \& Zhao, Y. (2002). Learning orientation, firm innovation capability, and firm performance. Industrial marketing management, 31(6), 515-524.

[13].Cangara, H. (2011). Pengantar Ilmu Komunikasi, Cet. XII. (Jakarta: PT.Rajagrafindo, 2011), h. 1819.

[14].Chaplin, J.P. (2011). Kamus Lengkap Psikologi. Diterjemahkan: Kartini Kartono. Jakarta: PT Radja Grafindo Persada.

[15]. Chao Cheng, Jong Lee., Li, Fen Tsai. (2012). Research On The Knowledge Sharing, Adventure Recreation And Performance Of Information System R\&D Personnel. International Journal of Organizational Innovation Online. Vol 5 (1): hal 1493-1513.

[16].Chatzoglou, P. D., \& Vraimaki, E. (2009). Knowledge-sharing behaviour of bank employees in Greece. Business Process Management Journal.

[17].Chang, H. H., \& Chuang, S. S. (2011). Social capital and individual motivations on knowledge sharing: Participant involvement as a moderator. Information \& management, 48(1), 9-18.

[18].Cheng, M. Y., Ho, J. S. Y., \& Lau, P. M. (2009). Knowledge sharing in academic institutions: A study of Multimedia University Malaysia. Electronic Journal of Knowledge Management, 7(3).

[19].Chiu, C. M., Hsu, M. H., \& Wang, E. T. (2006). Understanding knowledge sharing in virtual communities: An integration of social capital and social cognitive theories. Decision support systems, 42(3), 1872-1888.

[20].Connelly Catherine E., Kelloway E. Kevin. (2003). Predictors of employees' perceptions of knowledge sharing cultures. Leadership \& Organization Development Journal.

[21].Darmastuti, Rini. (2011). Teori Komunikasi Massa McQuail (Edisi 6). Jakarta : Salemba Humanika.
[22].Davenport, T. H., \& Prusak, L. (1998). Working knowledge, Boston. MA: Harvard Business School.

[23].Dawson, R. (2001). Knowledge Capabilities as the Focus of Organizational Development and Strategy. Journal of Knowledge Management. Vol. 4. No. 4. pp. 320327.

[24].Desouza, K.C. (2011). An introduction to knowledge management. In: K. C. Desouza and S. Paquette (Eds.). Knowledge Management: An Introduction (pp. 3-34).

[25].Dong, G., Gia Liem, C. and Grossman, M. (2010). Knowledge-sharing intention in vietnamese organizations. Vine Journal of Information and Knowledge Management Systems. Vol. 40 Nos 3/4. pp. 262-276.

[26].Everett M, Rogers. (2003). Diffusion of Innovation. 5th Edition. New York : Free Press.

[27].Fahimeh, B., \& Kermani, Z. J. (2011). Knowledge sharing behaviour influences: a case of Library and Information Science faculties in Iran. Malaysian Journal of Library \& Information Science, 16(1), 1-14.

[28].Fleming, M. L., \& Levie, W.H. (1981). Instrutional message design: Principles from the behavioral and cognitive science(pp. 9-11). Educational Technology.

[29].Godara, J., Isenhour, P., \& Kavanaugh, A. (2009, January). The efficacy of knowledge sharing in centralized and self-organizing online communities: Weblog networks vs. discussion forums. In 2009 42nd Hawaii International Conference on System Sciences (pp. 1-10). IEEE.

[30].Gillin dan Gillin. (1954). Cultural Sociology a Revision of an Introduction to Sociology. The Millan Company.

[31].Ghahtarani, Alireza. Majid Sheikhmohammady, Mahdieh Rostami. (2019). The impact of social capital and social interaction on customers' purchase intention, considering knowledge sharing in social commerce context https://doi.org/10.1016/j.jik.2019.08.004. Journal 
of Innovation \& Knowledge. https://www.journals.elsevier.com/

[32].Ghozali, I. (2009). Aplikasi Analisis Multivariate dengan Program SPSS. Semarang: UNDIP.

[33].Gurteen, D. (1999). Creating a knowledge sharing culture. Knowledge Management Magazine, 2(5), 1-4.

[34].Hanna, R., Rohm, A., \& Crittenden, V. L. (2011). We're all connected: The power of the social media ecosystem. Business horizons, 54(3), 265273.

[35].Hashim, K. F., Tan, F. B., \& Andrade, A. D. (2012). The Role of Trust and Commitment in Continuous Knowledge Contribution Intention within Business Online Communities. In CONFIRM (p. 9).

[36].Hashim, K. F., \& Tan, F. B. (2018). Examining the determinant factors of perceived online community usefulness using the expectancy value model. Journal of Systems and Information Technology.Diakses pada 20 Maret 2020. DOI 10.1108/JSIT-11-2016-0068.

www.emeraldinsight.com/1328-7265.htm

[37].Hashim, K. F., \& Tan, F. B. (2015). The mediating role of trust and commitment on members' continuous knowledge sharing intention: A commitment-trust theory perspective. International Journal of Information Management, 35(2), 145-151.

[38].Hemsley, J., \& Mason, R.M. (2013). Knowledge and knowledge management in the social media age. Journal of organizational computing and electronic commerce, 23(1-2), 138-167.

[39].Hendriks, P. (1999). Why share knowledge? The influence of ICT on the motivation for knowledge sharing. Knowledge and process management, 6(2), 91-100.

[40].Hennig Thurau, T., Gwinner, K. P., Walsh, G., \& Gremler, D. D. (2004). Electronic word-of-mouth via consumer-opinion platforms: what motivates consumers to articulate themselves on the internet?. Journal of interactive marketing, 18(1), 38-52.

[41].Hill, Virgil Zeigler and Shackelford ,Todd K. (2020). Retrieved March 15, 2020, from https://link.springer.com/referenceworkentry/

[42].Hoegl, M., Parboteeah, K. P., \& Munson, C. L. (2003). Team-level antecedents of individuals' knowledge networks. Decision Sciences, 34(4), 741-770.

[43].Hooper, D., Coughlan, J., \& Mullen, M. R. (2008). Structural equation modelling: Guidelines for determining model fit. Electronic journal of business research methods, 6(1), 53-60.

[44].Hsu, Chiu-Ping. (2015). Effects of social capital on online knowledge sharing: positive and negative perspectives. Online Information Review Vol. 39 No. 4, 2015 (pp. 466-484) (C) Emerald Group Publishing Limited 1468-4527 DOI 10.1108/OIR-12-2014-0314.

[45].Hsu, M. H., Ju, T. L., Yen, C. H., \& Chang, C. M. (2007). Knowledge sharing behavior in virtual communities: The relationship between trust, self-efficacy, and outcome expectations. International journal of human-computer studies, 65(2), 153-169.

[46].Hootsuite: Indonesian Digital Report. (2019). Hootsuite (We are Social): Indonesian Digital Report 2019. Diakses tanggal 20 Februari 2020, dari https://andi.link/hootsuite-we-are-socialindonesian-digital-report-2019/

[47].Ifinedo, Princely. (2017). Students' Perceived Impact of Learning and Satisfaction with Blogs. International Journal of Information and Learning Tehnology. Emerald Publishing. DOI 10.1108/ijilt-12-2016.0059.

[48].Ipe, M. (2003). Knowledge Sharing in Organization : Conceptual Framework, Human Resources Development Review (Vol. 2, No. 4, pp. 337-359).

[49].Islam, Z. M. (2010). The mediating effects of socialization on organizational contexts and 
knowledge sharing. Journal of Knowledge globalization, 3(1), 31-48.

[50].Jayasimha, K. R., Chaudhary, H., \& Chauhan, A. (2017). Investigating consumer advocacy, community usefulness, and brand avoidance. Marketing Intelligence \& Planning, 35(4), 488509. (C) Emerald Publishing Limited 0263-4503 DOI 10.1108/MIP-09-2016-0175.

[51].Ismail, J., Musa, A., Awis, M. L., \& Shari, S. The Performance of Academic Libraries: A Case Study at Research University (Rus) In Malaysia. Global Journal Of Human Social Science, 11(8).

[52].Kaplan, A. M., \& Haenlein, M. (2010). Users of the world, unite! The challenges and opportunities of Social Media. Business horizons, 53(1), 59-68.

[53].Kim, H. S. (2005). Consumer profiles of apparel product involvement and values. Journal of Fashion Marketing and Management: An International Journal.

[54].Kwahk Kee-Young, Hyunchul Ahn, Young U.Ryu. (2018). Understanding mandatory IS use behavior: How outcome expectations affect conative IS use. International Journal of Information Management, 38(1), 64-76. https://doi.org/10.1016/j.ijinfomgt.2017.07.001.

[55].Lee, Cynthia Chin Tian; Egbu, Charles; Boyd, David; Xiao, Hong; \& Chinyo, Ezekiel. (2005). Knowledge management for small medium enterprise: Capturing and communicationg learning and experiences. CIB W99 Working Commision 4th Triennial International Conference Rethinking and Revitalizing Construction, Safety, Health, Environment and Quality, Port Elizabent-South Africa, 17-20 May (pp. 808-820).

[56].Liebowitz, J. (2001). Knowledge management and its link to artificial intelligence. Expert systems with applications, 20(1), 1-6.

[57].Liliweri, A. (2009). Dasar-dasar Komunikasi Antarbudaya,Cet. IV(Yogyakarta: Pustaka Pelajar. h. 8.
[58].Lin, Y. J., \& Flores, L. Y. (2013). Job search selfefficacy of East Asian international graduate students. Journal of Career Development, 40(3), 186-202. Retrieved on Sep 9, 2015 from https://goo.gl/zEqoxb.

[59].Lin, H.F. (2007). Knowledge sharing and firm innovation capability: an empirical study. International Journal of Manpower, 28(3/4), 315-32.

[60].Ling, C. W., Sandhu, M. S., \& Jain, K. K. (2009). Knowledge sharing in an american multinational company based in malaysia. Journal Workplace Learning, 21(2), 125-142.

[61].Luarn, Pin, Hsieh, Ai-Yun. (2014). Speech or silence: The effect of user anonymity and member familiarity on the willingness to express opinions in virtual communities. Online Information Review. ISSN: 1468-4527. Publication date: 4 November 2014.

[62].Luo, C., \& Shrivastava, A. (2018, August). Jaccard affiliation graph (jag) model for explaining overlapping community behaviors. In 2018 IEEE/ACM International Conference on Advances in Social Networks Analysis and Mining (ASONAM) (pp. 1-8). IEEE.

[63].McDermott, R., \& O'dell, C. (2001). Overcoming cultural barriers to sharing knowledge. Journal of knowledge management, 5, 76-85.

[64].Mao, H., Liu, S., Zhang, J., \& Deng, Z. (2016). Information technology resource, knowledge management capability, and competitive advantage: The moderating role of resource commitment. International Journal of Information Management, 36(6), 1062-1074.

[65].Moradi, Mardan Farokh, Sardouyee Gholamreza. (2017). Relationship between Outcome Expectation and External Achievement Motivation with Self-Esteem among Depressed Patients. International Journal of Scientific Study August 2017 Vol 5 Issue 5. 
[66].Nasrullah, R. (2015). Media sosial: Perspektif komunikasi, budaya, dan sosioteknologi. Bandung: Simbiosa Rekatama Media, 2016, 2017.

[67].Nonaka, I., \& Teece, D.J. (2001). Managing Industrial Knowledge. London: SAGE Publication, L.td.

[68].Nonaka, I., Toyama, R., Konno, N. (2000). SECI, BA and leadership: a unified model of dynamic knowledge creation. Long Range Planning. Vol. 33.

[69].Nonaka, I. Takeuchi, H. (1995). The Knowledgecreating Company. Oxford University Press. New York, NY.

[70].Nurudin. (2011). Pengantar Komunikasi Massa. Jakarta : Raja Grafindo Persada.

[71].Olatokun, Wole M. \& Elueze, I. Nneamaka. (2012). “Analysing Lawyers' Attitude Towards Knowledge Sharing", SA Journal of Information Management, 14(1), 1-11.

[72].Onya, H., Aarø, L. E., \& Madu, S. N. (2009). Social outcome expectations regarding delayed sexual debut among adolescents in Mankweng, South Africa. Scandinavian journal of public health, 37(2_suppl), 92-100.

[73].Organ, D.W. (1988), Organizational Citizenship Behavior: The Good Soldier Syndrome, Lexington Books, Lexington, MA.

[74].Pasaribu, Manerep. (2009). Knowledge sharing Meningkatkan Kinerja Layanan. Perusahaan, Jakarta : PT Elex Media Komputerindo.

[75].Paul L. Tobing. (2007). Konsep Knowledge Management, Konsep, Arsitektur dan Implementasi, Graha Ilmu.

[76].Piliang, Y. A. (2004). Posrealitas: realitas kebudayaan dalam era posmetafisika. Yogyakarta: Jalasutra.

[77].Tsai, W., \& Ghoshal, S. (1998). Social capital and value creation: The role of intrafirm networks. Academy of management Journal, 41(4), 464-476.

[78].Qureshi, I., Fang, Y., Haggerty, N., Compeau, D. R., \& Zhang, X. (2018). IT-mediated social interactions and knowledge sharing: Role of competence-based trust and background heterogeneity. Information Systems Journal, 28(5), 929-955. First published: 04 January 2018.https://doi.org/10.1111/isj.12181

[79].Raharso, S. (2011). Pekerja pengetahuan (knowledge worker): Konsepsi dan tantangan pengelolaan. Jurnal Manajemen Usahawan Indonesia, 40(1), 58-74.

[80].Razak, N. A., Pangil, F., Zin, M. L. M., Yunus, N. A. M., \& Asnawi, N. H. (2016). Theories of knowledge sharing behavior in business strategy. Procedia Economics and Finance, 37(1), 545-553.

[81].Rozaq, K. (2014). Anteseden perilaku Berbagi Pengetahuan dan Pengaruhnya Pada Kemampuan Inovasi Perusahaan. Jurnal Bisnis dan Manajemen (Journal of Business and Management), 14(1), 77-92.

[82].Ryu, S., Ho, S. H., \& Han, I. (2003). Knowledge sharing behavior of physicians in hospitals. Expert Systems with applications, 25(1), 113-122.

[83].Saadé, R. G. (2007). Dimensions of perceived usefulness: Toward enhanced assessment. Decision Sciences Journal of Innovative Education, 5(2), 289-310.

[84].Senge, P. M. (1997). The fifth discipline. Measuring Business Excellence, 1(3), 46-51. ISSN: 1368-3047. Publication date: 1 March 1997.

[85].Sugiyono, P. (2015). Metode penelitian kombinasi (mixed methods). Bandung: Alfabeta.

[86].Sutisna. (2012). Perilaku Konsumen dan Komunikasi Pemasaran, Edisi Kedua, Bandung, Remaja Rosdakarya.

[87].Tohidinia, Z. and Mosakhani, M. 2010, .Knowledge sharing behaviour and its predictors, Industrial Management \& Data Systems, 110(4), 611-631. doi:10.1108/02635571011039052

[88].Utari, Prahastiwi. (2011). Perspektif Tujuh Tradisi dalam Teori Komunikasi. E journal Komunikasi Massa.

[89].Van Den Hooff, B., \& De Ridder, J. A. (2004). Knowledge sharing in context: the influence of organizational commitment, communication 
climate and CMC use on knowledge sharing. Journal of knowledge management, 117- 130.

[90].Wang, C. C., \& Yang, Y. J. (2007). Personality and intention to share knowledge: An empirical study of scientists in an R\&D laboratory. Social Behavior and Personality: an international journal, 35(10), 1427-1436.

[91].Wheaton, B., Muthen, B., Alwin, D., F., and Summers, G. (1977).Assessing Reliability and Stability in Panel Models. Sociological Methodology, 8 (1), 84-136.

[92].Wenger, E., McDermott, R. A., \& Snyder, W. (2002). Cultivating communities of practice: A guide to managing knowledge. Harvard Business Press.

[93].West, Richard \& Turner, Lynn H. (2008). Pengantar Teori Komunikasi:Analisis dan Aplikasi (Introduction Communication Theory: Analysis and Application, Jakarta: Salemba Humanika.

[94].Willem, A. (2004). The role of organisation specific integration mechanisms in inter-unit knowledge sharing (Doctoral dissertation, Ghent University).

[95].Wirtz, B. W., \& Göttel, V. (2016). Technology acceptance in social media: Review, synthesis and directions for future empirical research. Journal of Electronic Commerce Research, 17(2), 97-115.

[96].Wiertz, C., \& Ruyter, K. (2007). Online Communities. Beyond the Call of Duty: Why Customers Contribute to Firmhosted Commercial. Organization Studies, 2007, 28. doi:10.1177/0170840607076003.

[97].Wu, C., Lee, C. and Tsai, L. (2012), "Influence of creativity and knowledge sharing on performance", Journal of Technology Management in China, 7(1), 64-77. doi: 10.1108/17468771211207358

[98].Yusup, Pawit M. (2012). Perspektif Manajemen Pengetahuan Informasi, Komunikasi,
Pendidikan, dan Perpustakaan. Jakarta: PT Raja Grafindo Persada.

[99].Zawawi, A. A., Zakaria, Z., Kamarunzaman, N. Z., Noordin, N., Sawal, M. Z. H. M., Junos, N. M., \& Najid, N. S. A. N. (2011). The study of barrier factors in knowledge sharing: A case study in public university. Management Science and Engineering, 5(1), 59-70.

[100]. Zhou, Z. M., Zhang, J. L., \& Xiong, Y. P. (2014). How do introversion-extraversion personality traits influence knowledge sharing behavior in online brand communities: The mediation of network centrality and reciprocity norm. Nankai Business Review, 17(3), 19-29 (In Chinese)

[101]. Zhou, T. (2018). Understanding online knowledge community user continuance. Data Technologies and Applications.

\section{Cite this article as :}

Dwi Asih Haryanti, E. S. Margianti, Edy Prihantoro, Noviawan Rasyid Ohorella, "The Effect of Knowledge Sharing and Benefits on Sharing Intentions Through Social Interaction in Social Media Groups", International Journal of Scientific Research in Science and Technology (IJSRST), Online ISSN : 2395-602X, Print ISSN : 2395-6011, Volume 8 Issue 4, pp. 310-324, July-August 2021. Available at doi : https://doi.org/10.32628/IJSRST21848 Journal URL : https://ijsrst.com/IJSRST21848 